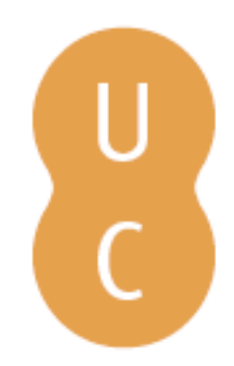

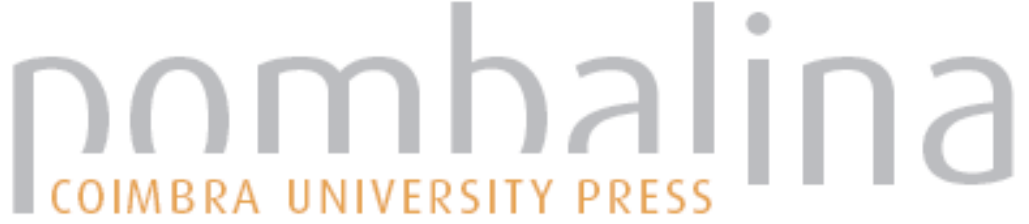

\section{Effects of training for sport on growth and maturation}

Autor(es): Malina, Robert M.

Publicado por: Imprensa da Universidade de Coimbra

URL

persistente: URI:http://hdl.handle.net/10316.2/38871

DOI: $\quad$ DOI:http://dx.doi.org/10.14195/978-989-26-1171-6_8

Accessed : $\quad$ 26-Apr-2023 09:57:42

A navegação consulta e descarregamento dos títulos inseridos nas Bibliotecas Digitais UC Digitalis, UC Pombalina e UC Impactum, pressupõem a aceitação plena e sem reservas dos Termos e Condições de Uso destas Bibliotecas Digitais, disponíveis em https://digitalis.uc.pt/pt-pt/termos.

Conforme exposto nos referidos Termos e Condições de Uso, o descarregamento de títulos de acesso restrito requer uma licença válida de autorização devendo o utilizador aceder ao(s) documento(s) a partir de um endereço de IP da instituição detentora da supramencionada licença.

Ao utilizador é apenas permitido o descarregamento para uso pessoal, pelo que o emprego do(s) título(s) descarregado(s) para outro fim, designadamente comercial, carece de autorização do respetivo autor ou editor da obra.

Na medida em que todas as obras da UC Digitalis se encontram protegidas pelo Código do Direito de Autor e Direitos Conexos e demais legislação aplicável, toda a cópia, parcial ou total, deste documento, nos casos em que é legalmente admitida, deverá conter ou fazer-se acompanhar por este aviso.

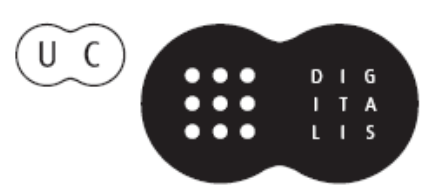



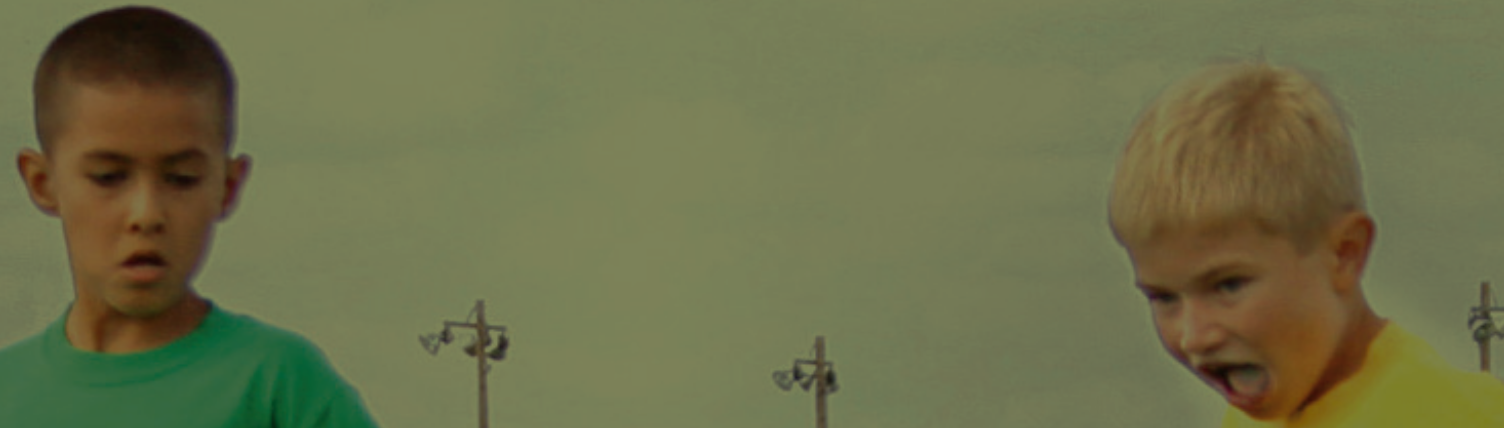

YOUTH SPORTS

\section{PARTICIPATION, $:$}

TRAINABHLTY TY

AND READINESSh

MANUEL J. COELHO E SILVA

ANTÓNIO J. FIGUEIREDO

MARIJE T. ELFERINK-GEMSER

ROBERT M. MALINA

EDITORS

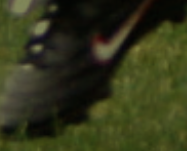

2. ${ }^{\circ}$ EDIÇÃO

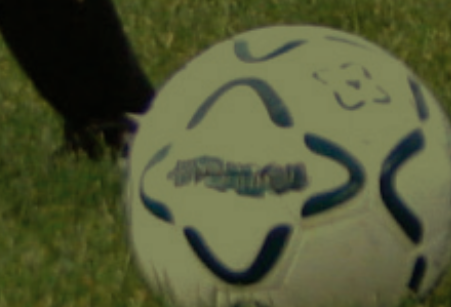

IMPRENSA DA

UNIVERSIDADE

DE COIMBRA

COIMBRA

UNIVERSITY

PRESS 


\section{CHAPTER 9: FUNCTIONAL RESPONSES OF CHILDREN AND ADOLESCENTS TO SYSTEMATIC TRAINING}

Robert M Malina

Joey C Eisenman

\section{INTRODUCTION}

Planned programs of instruction and training are basic to training for specific sports. Such programs have beneficial effects on several components important to athletic performance - motor skill, strength, and endurance. Evidence about specific training programs is often discussed in the context of the concept of the trainability, which refers to the responsiveness of children and adolescents at different stages of growth and maturation to an instructional or training program. This chapter first discusses the concept of trainability of children and adolescents, and then discusses the trainability of motor skill, muscular strength, and anaerobic and aerobic fitness.

- What is the concept of trainability?

- What are the responses of children and adolescents to training programs for motor skill, strength, and endurance.

\section{CONCEPT OF TRAINABILITY}

Trainability refers to the responsiveness of the individual to a specific training regimen. Trainability is related to the concepts of readiness and critical periods. It is often suggested, for example, that youth are more responsive to the beneficial effects of training during periods of rapid growth and maturation. The issue of trainability in the context of sport has been related primarily to the development of muscular strength and aerobic fitness, but it applies as well to the effects of instruction and practice on the development of motor skills, including sport specific skills. The term training, as used in this presentation, includes instruction and practice.

Discussions of trainability deal with two related, but different, questions: ( I) What are the responses of children and adolescents to systematic training programs? (2) How responsive are children and adolescents to specific training 
programs? The first deals with the effects of training programs, whereas the second deals with the trainability of children and adolescents.

The sensitivity of growing and maturing individuals to training depends on a variety of factors including age; perhaps sex; growth and pubertal status; prior experiences; pretraining levels of skill and physical fitness (current status); psychological factors; and probably genetics. With the exception of several studies of responses of sedentary young adults to aerobic or strength training, the factors indicated above are not generally controlled in studies of children and adolescents. Quality of instruction in the training environment is an

\section{TRAINABILITY OF MOTOR SKILLS}

The nervous system is, to a large extent, near adult form, and most basic movement patterns are reasonably well established by 6 to 8 years of age, ages when many children have their first experiences in youth sports. It might be expected, therefore, that these ages would be ideal for specific instruction and practice in the basic motor skills.

Instruction and practice have a beneficial influence on skill acquisition in early childhood and during the transition into middle childhood (Malina, 2008). Guided instruction by qualified coaches or trained parents, appropriate motor task sequences, and adequate time for practice are essential components of successful instructional programs at young ages. Focus has been largely on general movement skills in contrast to sport-specific skills. Nevertheless, casual observation of the progress of children during a season of supervised instruction, practice and competition in a given sport clearly shows improvements in general and sport-specific skills. Modifications of sports such as small-sided soccer provide many opportunities for more touches and in turn refinement of ball handling skills.

More systematic approaches are needed to document the specific influence of instruction and practice in a sport on the movement skills of youth. A recent example is a comparison of the motor skills (though not sport-specific skills) and physical fitness of 7 and 8 year old boys exposed to three sessions of soccer instruction and training per week over a nine month period in addition to school physical education and age peers who received only physical education instruction (Erceg et al., 2008). Outcome variables were components of motor proficiency and fitness: coordination, agility, flexibility, movement speed, explosive strength, muscular strength and endurance, static strength and aerobic endurance. On average, boys involved in the soccer program made greater gains than control peers in motor proficiency and fitness over the nine months. 
Although the results are interesting, they are limited from two perspectives: boys were not assigned to the soccer and control groups randomly, and body size was not statistically controlled in the analysis. Boys in the experimental group were already enrolled in soccer schools at the start of the study. Growth status per se and changes in growth status over nine months may influence performances on some of the tests used in the study. At these ages, it may be difficult to partition learning effects from those associated with growth and maturation. Motor performance improves more or less linearly with age during middle childhood. It continues to improve during adolescence in males, but tends to reach a plateau or to improve only slightly in females after I4- 15 years (Malina et al., 2004a).

Related variables also need to be considered in evaluating the influence of sport programs on skill development. Perhaps most important is the environment of sport programs - instructional and practice protocols, quality of coaches and coaching styles, parental involvement and the overall atmosphere of the setting (child-focused, relaxed).

Instruction and practice in movement skills per se and in combinations or modifications of these skills to meet the requirements of specific sports, are beneficial during middle childhood and adolescence. Data dealing with skill acquisition at older ages are, with few exceptions set within the framework of cognitive psychology and relate to relatively simple, discrete movement tasks in contrast to more complex tasks of a sport.

Application of principles of skill acquisition to soccer skills have been summarized (Williams et al., 2003; Williams and Hodges, 2005). Individual differences in age, size, maturity status, fitness, skill, and motivation of young athletes (internal constraints), especially during the transition into puberty and during the adolescent growth spurt and sexual maturation, present a challenge in applying these principles to youth players. In adolescent soccer players 13I5 years of age, for example, age, experience, body size and stage of puberty contribute significantly to indicators of functional capacity (aerobic, power, speed), but considerably less to soccer-specific skills (Malina et al., 2004b, $2005,2007)$. The challenge is to incorporate individual differences in internal constraints into instructional and practice situations (environmental constraints) to facilitate the acquisition and refinement of skills.

\section{TRAINABILITY OF MUSCULAR STRENGTH}

Resistance exercise programs typically involve the use of weights or specially designed machines to provide the resistance against which a particular muscle 
group must work. Historically, resistance training for the development of strength was not recommended for prepubertal children (those who do not show the overt manifestations of puberty). This view suggests that prepubertal children are not as responsive to strength training as pubertal or postpubertal youth. Many studies in boys and girls $5-11$ years, however, indicate that they respond to resistance training with gains in strength (Blimkie and Sale, 1998; Sale, 1989; Malina, 2006).

Although prepubertal children respond to resistance training with gains in muscular strength, they show no or only minimal muscular hypertrophy (increase in muscle size). The relatively small changes in muscle size compared to gains in strength suggest that the response to the resistance training stimulus in prepubertal children is largely changes in the nervous system. The nature of the responses is not known with certainty, but probably includes changes in the coordination of the nervous system.

Variation among individuals in response to strength training programs is not ordinarily considered or reported. Do all children respond in a similar manner? The answer is no. Are there an age-related effects on the response to training? Some data suggest smaller strength gains in absolute strength in younger children. Other questions that arise in discussions of strength training deal with possible differences in responses of boys and girls, and of chidren who vary in pubertal status. Although there is no sex difference among prepubertal children, the issue of sex differences has not received adequate study. Variation in response to training by pubertal status suggests greater percentage increases in strength by prepubertal boys, followed in order by pubertal and postpubertal boys has received some consideration. On the other hand, absolute strength is probably less trainable in prepubertal than in pubertal and postpubertal youth (Malina, 2006).

The preceding studies focus on resistance training designed to increase strength. Programs designed to improve muscular endurance also result in strength gains, but some evidence suggests that younger boys make greater relative gains in strength, whereas older boys make greater relative gains in muscular endurance (Malina et al., 2004a). The results suggest differential responses to the type of training stimulus that depend upon age.

The persistence of strength gains in children and adolescents after the cessation of resistance training needs further study. Limited data for prepubertal children indicate that gains in strength associated with resistance training tend to revert to control values several weeks after the cessation of training. A related issue is the amount of training needed to maintain strength gains associated with training in children and adolescents. Presently available 
information on the training requirements for the maintenance of strength gains is not conclusive.

An issue of importance in strength training studies is the influence of the strength training on other aspects of performance. In other words, does strength training transfer to athletic performance? Data that address this question are limited.

In a study of girls 9-17 years of age, those who did isometric strength training also improved in the vertical jump and acceleration in sprint running, and girls who did vertical jump training also improved in isometric strength and acceleration in sprint running (Nielsen et al., 1980). Gains were greater in the domain that was specifically trained, i.e., girls who did isometric training made greater relative gains in isometric strength and girls who did vertical jump training made greater relative gains in the vertical jump.

Other data dealing with transfer of strength training to other aspects of performance are limited. A study of boys 6- II years suggests improvements in the vertical jump and flexibility (sit and reach) after 14 weeks of resistance training, whereas a study of a combined sample of boys and girls 7- 12 years suggests negligible changes in the vertical jump and the sit and reach after 8 weeks of training. The variable duration of the training programs may contribute to the different results (Malina, 2006). Further, it is difficult to partition the effects of the training program from expected changes in performance associated with normal growth.

\section{TRAINABILITY OF ANAEROBIC FITNESS}

Many youth sports are characterized by activities that involve short bursts that rely on anaerobic fitness. For example, a batter sprinting to first base, a running back dashing towards the goal line, or a soccer player running to a pass. Anaerobic fitness is influenced by growth and maturation, and possibly by specific anaerobic exercise training (Malina et al., 2004a).

Information regarding the trainability of anaerobic fitness in children and adolescents is limited, and it is not clear whether anaerobic fitness is trainable in children and adolescents. Some studies, but not all, show greater anaerobic fitness in athletic youth compared to non-athletic youth. Experimental training studies suggest that anaerobic fitness can increased to some extent following a period of high-intensity training, but the data are limited to two studies of boys 10 to 13 years of age. 
It appears that puberty is a critical period in the development of anaerobic fitness due to changes in body size, muscle mass, short-term ability of muscle to generate energy, and hormones associated with sexual maturation. Neural factors may also contribute to changes in anaerobic tasks associated with training.

There are moderately strong relationships between laboratory measures of anaerobic fitness and field performances. This suggests the potential for transfer of training-related improvements in anaerobic power to short-burst activities involved in many sports. Changes in anaerobic fitness with training are also probably related to improvements in the ability to resist fatigue during short-term, high-intensity intermittent bouts of activity such as repeated sprints (Malina and Eisenmann, 2003).

\section{TRAINABILITY OF AEROBIC FITNESS}

The ability of the child or adolescent to perform under predominantly aerobic conditions is a major component of endurance performance. Aerobic power is the maximal amount of energy that can be transformed in the aerobic machinery of working muscle fibers per unit time (usually per minute). It is usually measured as maximal or peak oxygen consumption ( $\mathrm{VO}_{2}$ peak) as the youngster nears exhaustion while running on a motorized treadmill or cycling on a bicycle ergometer. It is quite difficult to obtain good measurements of aerobic power in children 10 years of age and younger.

A question of interest is the response of aerobic power to systematic endurance training, i.e., the trainability of $\mathrm{VO}_{2}$ peak. Available data for short term experimental studies indicate relatively little trainability of maximal aerobic power in children under 10 years. Changes in $\mathrm{VO}_{2}$ peak per unit body weight in children under 10 years with systematic training are generally small less than 5\% (Malina et al., 2004a). It is not certain whether these results reflect low trainability of aerobic power or inadequacies of training programs. If it can be assumed that young children are habitually more physically active than adolescents and adults, a more intensive aerobic training program may be required to induce changes in maximal aerobic power.

Among older children and adolescents, responses of aerobic power to training improve. Youth training for a variety of sports usually have higher aerobic power, both in absolute terms (liters of oxygen per minute) and per unit body weight (Malina et al., 2004a). In addition, individual differences in response to aerobic training are considerable. For example, among 35 boys and girls, 10.9 to 12.8 years, who participated in a 12 week aerobic training program, the average change in $\mathrm{VO}_{2}$ peak per unit body weight was $6.5 \%$. 
However, responses ranged from $-2.4 \%$ to $19.7 \%$ of the young adolescents (Rowland and Boyajian, 1995). Thus, average values may be misleading.

The experimental studies of the effects of systematic endurance training are short term and ordinarily do not include a follow-up component. As a result, there is lack of information on the persistence of improvements in aerobic power after the cessation of training, and on the amount of training needed to maintain the improvements.

It is generally assumed that improvement in $\mathrm{VO}_{2}$ peak will be associated with improved endurance performance. Running has received more attention than swimming in this regard. Among young distance runners, $\mathrm{VO}_{2}$ peak is closely related to performance in the 1 to 3 mile run. However, improved running performance during childhood and adolescence is influenced by other factors besides of $\mathrm{VO}_{2}$ peak. These include, for example, changes in body size associated with normal growth and maturation, running economy and anaerobic power.

\section{OVERVIEW}

- Motor skills in general and specific sport skills can be improved with systematic programs of instruction and practice.

- Prepubertal boys and girls respond to resistance training programs with gains in strength, but with minimal or no muscular hypertrophy. There is no sex difference in the response to resistance training among prepubertal children. The strength gains reflect changes in the nervous system.

- $\quad$ Regarding strength training for young prepubertal children, two different questions are usually asked as one: (1) How important is strength training for 8-9 year old children? - The answer is not known; motor skill training is probably more important. (2) Do 8-9 year old children respond to a strength training program? - Yes, with increased strength.

- Pubertal boys respond to resistance training programs with increases in strength and muscular hypertrophy. Increase in size of a muscle is a late training effect. The responses reflect neural and endocrine effects; the latter are associated with the growth spurt and sexual maturation.

- Pubertal girls also respond to resistance training programs with increases in strength, but with minimal hypertrophy. The latter reflects sex differences in hormonal changes during puberty. 
- Data are less extensive for training programs that focus on muscular endurance. Limited data suggest that younger boys make greater relative gains in muscular strength, while older boys make greater gains in muscular endurance.

- $\quad$ Limited data suggest that anaerobic fitness can be improved following a period of high-intensity training. Anaerobic fitness increases considerably during puberty and the growth spurt due mainly to changes in body size and muscle mass, and the capacity of muscle to generate short-term energy.

- Presently available data indicate relatively little trainability of maximal aerobic power $\left(\mathrm{VO}_{2}\right.$ peak) in children under 10 years of age. It is not known if these results are the consequences of low trainability (low adaptive potential to aerobic training) or to inadequacies of the training programs.

Among older children in the transition into puberty/adolescence, and among adolescents, responses to aerobic training are enhanced. Responses are generally similar to those observed in young adults and sex differences are minimal. Studies are confounded by individual variation in the timing and tempo of the growth spurt and sexual maturation. In addition, maximal aerobic power shows its own well defined adolescent growth spurt.

\section{LITERATURE}

Blimkie CJ, Sale DG (1998) Strength development and trainability during childhood. In E Van Praagh (Ed): Pediatric Anaerobic Performance. Champaign, IL: Human Kinetics, pp 193-224.

Erceg M, Zagorac N, Katic R (2008) The impact of football training on motor development in male children. Collegium Antropologicum 32:241-247.

Malina RM (2006) Weight training in youth-growth, maturation, and safety: an evidence-based review. Clinical Journal of Sports Medicine 16:478-487.

Malina RM (2008) Skill: Acquisition and Trainability. In O Bar-Or and H Hebestreit (Eds), The Young Athlete. Oxford, UK: Blackwell Publications, pp 96-I I I.

Malina RM, Bouchard C, Bar-Or O (2004a) Growth, Maturation, and Physical Activity, 2nd edition. Champaign, IL: Human Kinetics.

Malina RM, Cumming SP, Kontos AP, Eisenmann JC, Ribeiro B, Aroso J (2005) Maturity-associated variation in sport-specific skills of youth soccer players aged 13- 15 years. Journal of Sports Sciences 23:5 I5-522.

Malina RM, Eisenmann JC (2003) Trainability during childhood and adolescence. In RM Malina, MA Clark (Eds), Youth Sports: Perspectives for a New Century. Monterey, CA: Coaches Choice, pp 76-93. 
Malina RM, Eisenmann JC, Cumming SP, Ribeiro B, Aroso J (2004b) Maturityassociated variation in the growth and functional capacities of youth football (soccer) players 13-15 years. European Journal of Applied Physiology 91:555-562.

Malina RM, Ribeiro B, Aroso J, Cumming SP (2007) Characteristics of youth soccer players aged 13-15 years classified by skill level. British Journal of Sports Medicine 41:290-295.

Mirwald RL, Bailey DA (1986) Maximal Aerobic Power. London, Ontario: Sport Dynamics.

Nielsen B, Nielsen K, Behrendt Hansen M, Asmussen E (1980) Training of "functional muscular strength" in girls 7-19 years old. In K Berg, BO Eriksson (Eds). Children and Exercise IX. Baltimore: University Park Press, pp 69-78.

Rowland TW, Boyajian A (1995) Aerobic response to endurance exercise training in children. Pediatrics 96:654-658.

Sale D (1989) Strength and power training during youth. In CV Gisolfi, DR Lamb (Eds): Perspectives in Exercise Science and Sports Medicine. Volume II. Youth, Exercise, and Sport. Indianapolis. Benchmark Press, pp I65-2 I6.

Williams AM, Hodges NJ (2005) Practice, instruction and skill acquisition in soccer: Challenging tradition. Journal of Sports Sciences 23:637-650.

Williams AM, Horn RR, Hodges NJ (2003) Skill acquisition. In T Reilly, AM Williams (Eds), Science and Soccer, $2^{\text {nd }}$ edition. London: Routledge, pp 198-2/3. 